\title{
The Effectiveness of Customary Law to Protect Natural Resources in The National Park in Central Sulawesi
}

\author{
Agus Lanini' ${ }^{1}$, S. Yodo ${ }^{2}$ \\ ${ }^{1,2}$ Tadulako University, Bumi Tadulako Tondo Campus, J1. Sukarno Hatta Km.9 Palu, \\ Sulawesi Tengah, Indonesia \\ agusalanini@gmail.com; aguslanini@untad.ac.id ${ }^{1}$
}

Article History: Received: 10 November 2020; Revised: 12 January 2021; Accepted: 27 January 2021; Published online: 05 April 2021

\begin{abstract}
Most of the local communities living around the forest fulfil their daily needs, depending on the forest resources, but the government and even global policy have enacted the forest as a protected area or national park. The purpose of this research is to understand and explain the principles of customary law concerning the natural resources that exist in the national park, and to determine the effectiveness of customary law in protecting these natural resources. The research method applied to explore community values and attitudes is socio-legal. The research revealed society's habits through exploration, and norms and the rule of law are embraced. Some principles of customary law on natural resources include palia (taboo) and ombo (prohibition) pertinent to natural resource conservation. Both of these principles are adhered to and have been hereditary. The values on utilising natural resources are still complied with (effective), although state law takes a formal approach for any infringement surrounding the national park. However, customary law principles still always need to be a source for environmental or related law.
\end{abstract}

Keywords: Customary Law; Natural Resources; Effectiveness; National Park

\section{Introduction}

The relation between local communities and environment surround the forest are a mutual benefit or symbiosis mutualism. Most of the local com munities needs are available in the forest and its entirely become part of biological resource and natural environment. However, during sustainability government policy which forest become a protected area since its determined as national park by government (Acciaioli, 2008; Murray Li, 2000; UURI 5/1990 KSDAE, 1990; UURI 41/1999 UUK, 1999).

Lore Lindu as the forest keep valuable natural resource which determined by the government in conformity to decree of agricultural ministry No. 736/Mentan/X/1982 dated on October 14, 1982. Previously, there were conserved area: wildlife reserve Lore Kalamanta with 1351,000 hectares, and shelter forest with 31,00 hectares. Based on the provision the total vast of Lore Lindu National Park was approximately 229,000 hectares located in Sigi and Poso Districts (Deschamps \& Hartman, 2005; Harwell \& Lynch, 2002; Mehring \& Stoll-Kleemann, 2011).

Technological developments and community growth are having an effect on the parks or on the natural resources in the parks. There are 67 villages surrounding this area with a population of about 69.000 inhabitant and it tends to increase every year so that it becomes a burden on the environment or natural resources in meeting their daily needs (BPS Kabupaten Poso, 2018a, 2018b; BPS Kabupaten Sigi, 2018a, 2018b).

The increase in population was affected by births and migration from various regions, both within the Central Sulawesi province and from outside the province. They came to this region to fulfill and improve their economy. The migrant gets access to utilize natural resources after being allowed by the village head and / or customary institution, but there are also transactions in the form of buying and selling farm land..

The development was also influenced by better transportation facilities. The highway has connected one village to another and even the highway has penetrated the core zone of the national park that connects Sigi district with Poso district. This has the potential to suppress and even threaten the preservation of natural resources contained in national parks. Because land limitations are increasingly felt and the necessities of life are increasing, several problems arise, such as illegal logging and even illegal mining which is seen as a violation by the national park manager or Lore Lindu National Park.

Since the forest area was a protected then local communities are not allowed to entrance the forest, even though they were there before for centuries, means the relation between human and nature were developed as symbiosis mutualism. Due of the enacted regulation arisen uncertainty for local communities but opportunity for the other communities, consequently, national park as conservation area there were many changes or destruction done by human activities in the area, for example illegal loggings, slash cutting and burn (land inauguration). 
People did these activities ignoring the preservation of the environment (Clifton et al., 2014; Deschamps \& Hartman, 2005; Harwell \& Lynch, 2002; Hidayat, Sinukaban, Pawitan, \& Tarigan, 2007; Murray Li, 2000).

The clearing or inaugurations of the forest were destructive activities which destroy the ecosystem of the forest. Even though, the regulation obliges the community to conserve the environment but they still disobey it, and forest destruction still taken place.

However, people who live surround the national park belief that customary law as their guidance for two things; First of all the values in related to the God as the creator and the second was the values in related to the human and nature. Each of the both values called katuvua and huaka. Customary law determined many command and forbidden in using natural resources as traditional conservation. Despite people from outside who come to encroached the forest has been trial proceed there were many local people have been sentenced. But the national park gradually decrease (Fathoni, 2013; Gantika \& Wibowo, 2013; Herriman, 2017; Keil, Zeller, Wida, Sanim, \& Birner, 2008; Li, 2001).

The customary guideline of the Kulawi, Kaili, and Pekurehua communities is pleased with the management of natural resources which has been firmly applied to anyone who commits an offense. However, because national park authorities often prioritize state law which is relatively incompatible with a sense of justice, the people around the national park still respect their customary law.

The purpose of this research is to know and explain the principles of customary law concerning the natural resources that exist in the national park and to find out the effectiveness of customary law concerning the using of natural resource around national parks. However, customary law as their living law are still as the primary sources toward controlling the communities behaviour in around the national park (Burkard, 2002; Moeljoprawiro \& Faqih, 1998; Schrijver, 1997)

The research contributed to develop the environmental law that enacted as a part of government policy. Actually, these law merely faced many constraint in its implementation due of the weakness (uneffective). Meanwhile, people needs the rules to protect the park that came from the values adopted in the customary law principles.

\section{Research Method}

The research conducted in three area in two regency covered of Sigi and Poso. Pololo and Kulawi are laid in Sigi regency and Lore Utara laid in Poso regency. Palolo inhabitant dominate with Kailis tribe where site adjoin to the national park and Kulawi population majority with Kulawis Moma tribe which adjacent to the national park.

The research applied socio-legal through investigation or exploration of realities established in the society and social facts (Banakar, 2015; Blandy, 2016; Hertogh, 2018). Data collection carried out through the table list below:

Table 1. List of method and data collection

\begin{tabular}{|l|l|l|l|}
\hline Activities and villages & Observation & Interview & Discussion \\
\hline Petimbe & $\sqrt{ }$ & $\sqrt{ }$ & \\
\hline Sedoa & $\sqrt{ }$ & $\sqrt{ }$ & \\
\hline Watumaeta & $\sqrt{ }$ & $\sqrt{ }$ & $\sqrt{ }$ \\
\hline Marena & $\sqrt{ }$ & $\sqrt{ }$ & $\sqrt{ }$ \\
\hline Toro & $\sqrt{ }$ & $\sqrt{ }$ & \\
\hline
\end{tabular}

Sources: Field data

Observation to examine the people's attitude toward their environment, both physical and social environment, such as obedience to comply customary law or state regulation. Interview with some village figures such actors with their important role in the communities, including head of village. The respondent determined by validity of the information source; the respondents lived in the research location. There were 20 people from each villages. Focus group discussion to collect community's opinion regarding their attitude toward their surroundings both social and physical environment. The participants involved in this session are a certain group whose not yet as a respondent of interviewer or observation in order to find a comprehensive data or information. 


\section{Result and Discussion}

\section{Principles of customary law and state law concerning to protect the natural resources}

At the beginning, exploitation of the natural/forest resources tend to very intensive of exploitation taken place when the villagers reside in the vicinity of national park since they had reasonable reasons to do this: they were under economic pressure (Harris AO, 2016) and attractive offer from the investors (Booth \& Halseth, 2011), neighborhood villagers committed such activities like, and omitted by ranger (FGD, 2019).

However, according to the local belief who reside in the vicinity of Lore Lindu national Park, there were karampua and tomanuru as the lord of earth, sky and ocean. The creator of universe, owing to this karampua and tomarunu ascendance the happiness and infliction. The villagers believe that karampua would gave indication if the customary agency did not afford to decide a solution for any violation (customary law).

The Indigenous People of Kulawi (To Kulawi) in one of its kinship systems that regulates human relations with nature has a system called Katuwua / Popahi lolonga Katuwua. This system adheres to 2 (two) basic principles, namely: (1) Toi Petagi, (2) Toi Popalia. Toipetagi is taboo. There are absolute principles and ones that are not absolute. Like not being allowed to open a forest or cultivate a forest where there is a spring "ue ntumu", ue bohe eyes prohibit aligning and cutting timber in the riverbed or small times in the forest or even river mills / small streams those who pass through the settlements when cutting down forests are not allowed to cut down trees that are known to have the efficacy of traditional medicines. Banyan tree, and Gnetum gnemon tree.

While restrictions that are not absolute, such as, are prohibited from carrying forest products and bringing them home through rice during the pramodia. Prohibition of opening forests where amboina pitch trees are known, and opening up forests to the top of the mountain "nemo mobone maratai pongku Bulu". Prohibition of cutting down wood which is known as staple food for birds or other animals in the forest.

The indigenous people of Kulawi who live around the mountainous nature which are rich in biodiversity are groups of people who have traditionally had traditional wisdom concepts in utilizing natural resources responsibly.

They have applied the traditional concept of utilizing natural resources "popahilo longa katuwua" in that concept "katuvua" it is believed that on this Earth Persada (I wongko lino) there are three elements of life that have a reciprocal relationship, grow and multiply and support each other namely humans (tauna), animals (pinatuwua), and plants (tinuda / hinua)..

The national park area produces a variety of natural resources needed to meet the living needs of the surrounding community. Even, these natural resources are abundant (surplus), because they are not exploited on an economic scale. But it is only used to the extent that the living needs of the surrounding community are based on the principles of customary law that are obeyed (Booth \& Halseth, 2011; Burkard, 2002; Erasmi, Twele, Ardiansyah, Malik, \& Kappas, 2004).

Some indicators of the principles of customary law regarding how to protect the natural resources around the national park as well as state law can be seen in the following table:

Table 2. The protection principles of natural resources around national park

\begin{tabular}{|l|lll|}
\hline Kinds of principles & Customary Law & State Law & Remark \\
\hline Useful & Ombo & Permit & Certain period \\
\hline Sustainability & Ombo rano & Permit & Certain period \\
\hline Populist & Ombo & Permit & Certain period \\
\hline Participative & Palia & Protected & Prohibition \\
\hline Justice & Taolo and dumpolo & Protected & Prohibition \\
\hline $\begin{array}{l}\text { Transparency } \\
\text { Integrated }\end{array}$ & $\begin{array}{c}\text { Ombo } \\
\text { Palia and Ombo }\end{array}$ & Permit & \\
\hline Sourtain period
\end{tabular}

Source: Field data

Generally, villagers still adhere to the customary law and obey the penalty was given by customary agency. It was suitable to the interview and observation result. The villages were remote from the city and enable the villagers to maintain their traditions as the guidance of their daily activities. 
Ombo was a prohibition to perform activities in a certain time. Ombo was carried out when village figures or his inheritance passed away, madika and inheritance, totua ada and inheritance. Ombo was relevant to death people. Ombo begun at the seventh day after someone's death which ombo performed for him. The implementation of ombo decided through discussion of the customary boards and they also decided certain places of ombo, in land and in lake (rano) and kinds of ombo.

Ombo petora or ombo kiki was prohibition for the villagers not to catch the fish in the lake, in interval time of 40 days, ombo kiki was prohibition not to cut off the trees, exploit the forest, hut the animals in interval time of a year. The start and finishing of ombo would be announced by totua ada. Someone who committed ombo was calls as pecunda ombo and the given penalty for him was to pay all funeral and wedding cost. It was the heaviest penalty for the infraction of ombo.

Customary leader in local terms was known as totua ada. He was respected by the villagers because of their spiritual power. Totua ada was elected amongs the figures who were assumed having knowledge of the traditions. Totua ada as the leader of tradition have authority to give solution when there were infraction to the traditions. For instance if someone would build a house, he should ask totua ada about the kind of appropriate wood, the better time to cut off the trees, because if the man cut off the young trees or cut off not in the right time, the timber would not be good for building materials.

In the local administration, totua ada always took part in every meeting. The villagers always ask the opinion of totua ada such as in the election of candidate of head of village. He was assumed know the personality of the candidate. Totua ada as represent of Lembaga adat determined ombo as the grace of the villagers to totua ada because when he has valuable contribution for the community.

Generally the villagers still obey the customary law agency, based on the interview with some villagers they said that totua ada was respected since his conduct suitable with his utterances, due to this the villagers highly appraise tota ada. The obedience of the villagers to totua ada also describe the importance of natural conservation since in the traditions are legalized as customary law, that it is forbidden to cut off the trees randomly without permission from tatua ada. If someone broke the law (palia) then it would cause danger to the environment.

Palolo and Kulawi people or Lore Lindu community believe that Palia was able to give catastrophe if the people disturb it. Some trees were forbidden to be cut off such as:

a. Banyan trees, appears as eerie and leafy trees and there was belief that the guardian spirit cannot be annoyed.

b. Areca nut (sarao), there were a lot of such trees planted in national park gave beautiful view and advantageous, the leaf can be used as roof, the stem can be used as food container, people believe that spirit like inhabit this tree.

c. Wild pandanus have hanging roots and people believe that spirit like inhabit this tree.

There was a society faith to forbid the cut off of the three kinds of trees since the tutelary spirit would assign catastrophe if it was irritated. The meaning of palia can be understood as an effort to conserve the forest, since if the trees were cut off and extinct the function of trees would be lost as well as the its absorbance function

The customary law palia was considered to be a guidance of the relation between human beings with their environment. If the awareness of the society aroused because of their belief or self-aware then, there would no reason to say that the customary law would be no longer established. The implementation of law cannot be equated with positive law implementation because customary law exists from the society's tradition. Customary law exist in the society since its justice was suitable to the society.

The implementation of customary law principles in using forest as natural resources should follow the criteria below:

Table 3. Criteria and status of the forest protection

\begin{tabular}{llll}
\hline Name/ call name & Density/Natural condition & Prohibition & Age of forest \\
\hline Hurapa & Less/ on the top of mountain & Yes & \\
\hline Wana & Jungle & Yes & Yes \\
\hline Ponulu & Primary forest & No* & \\
\hline Penulu biasa & Secondary forest & No** & $>25$ years \\
\hline Pahawa Pongko & Secondary forest & Yes*** & $16-25$ years \\
\hline Oma & $\begin{array}{l}\text { Extinct plantation } \\
\text { forest }\end{array}$ & & \\
\hline
\end{tabular}




\begin{tabular}{|c|c|c|c|}
\hline Oma tua & $\begin{array}{l}\text { Extinct plantation/ } \\
\text { exuberant }\end{array}$ & Yes**** & $16-25$ years \\
\hline Oma kungku & Extinct plantation meadow/ un-exuberant & & $2-3$ years \\
\hline Oma nete & Extinct plantation & & -- a year \\
\hline
\end{tabular}

Source: Field data

Note:

* the forest is accessible but the product cannot be owned.

$* *$ The forest accessible and owned according to the decision of customary law

$* * *$ The owner of annual plant still acknowledged

The head of village or totua ngata decided the criteria based on the findings then submit to the customary agency, (totua ngata tongnica metutuna). Then, they would decide whether they would bestow the appeal of the villagers or would not.

Besides, the way of natural exploitation would observe the physical condition of the targeted location whether it would not infract the law provisions such as preclude kaolo, spring, and the condition of the land that was too slantwise. Fremerey views that the determination of such natural conservation was the local wise founded by the learning process of establishing the independent organization (Fremerey, 2002).

\section{The effectiveness of customary law regarding natural resources around the national park}

The customary law principle was considered to be a guidance of the relation between human beings with their environment. If the awareness of the society aroused because of their belief or self-aware then, there would no reason to say that the customary law would be no longer established. The implement tation of law cannot be equated with state law because customary law exists from the society's tradition. Its exist in the society since its justice was suitable to the society needs.

Frankly, there is no society without any infringement so do in the research site where arise phenomena of encroachment the natural resources in the national park. However, its aware the communities to preserve through their local knowledge as customary law.

So far, state law relating to the protection of natural resources, both generally accepted and specifically regulating national parks, have existed, but legal violations still occur in the area. Enforcement of law carried out by the national park authority experiences various obstacles such as the lack of forestry police (rangers), vehicle facilities and communication tools, the involvement of officials both as perpetrators and protectors of violators.

Legal provisions that generally regulate the protection of natural resources such as environmental laws (UURI 32/2009 PPLH, 2009), forestry laws (UURI 41/1999 UUK, 1999), mining laws (UURI 4/2009, 2009), the enactment of the law of combating forest demager (UURI 18/2013, 2013).

While the statutory provisions that specifically regulate national parks such as conservation law (UURI 5/1990 KSDAE, 1990), Central Sulawesi regional regulation on the buffer zone of the national park (Perda Sulteng DPTNLL, 2006). Both of the provision whether general or specific over national park are not effective to protect the natural resources.

Some forms or types of violations of statutory provisions relating to the use of natural resources around the Lore Lindu National Park. This can be seen from the contents of the articles that regulate it as follows:

Table 4. Form of violation of statutory provisions

\begin{tabular}{|llllll|}
\hline Regulation/ Violation & Law/ 41/1999 & Law/ 32/2009 & Law/ 5/1990 & Law 18/2013 & $\begin{array}{l}\text { Regional } \\
\text { Reg 6/2006 }\end{array}$ \\
\hline Logging & Art.50.3.c & Art.67 & Art.33 & Art.11 \& 12 & Art.23.2 \\
\hline Encroachment & Art.50.3.b & Art.67 & Art.33 & Art.11 \& 12 & Art.22.2 \\
\hline Slash \& burn & Art.50.3.d & Art.67* & Art.33 & Art.11 \& 12 & Art.22.2 \\
\hline Mining & Art.50.3.g & Art.67 & Art.33 & Art.11 \& 12 & Art.22.2 \\
\hline Fishing & & Art.67 & Art.33 & Art.11 \& 12 & Art.22.2 \\
\hline Plantation & & Art.67 & Art.33 & Art.11 \& 12 & Art.22.2 \\
\hline
\end{tabular}

Sources: research data 
Based on the table, it can be seen a number of violations of the provisions of the law as a State law. Illegal logging occurs around the periphery to the core zone of the national park. The perpetrators of illegal logging are usually residents from outside the village around the national park in collaboration with local residents but they are given capital by the owners of capital.

Encroachment and logging and burning carried out by local residents who want to open a garden. In addition they are also looking for rattan and resin as non-timber forest products but are of economic value. Because it was carried out in a hurry, many plants or trees were cut down to make it easier to extract the non-timber forest products.

Mining takes place in the core zone in the form of illegal mining which is actually carried out by outsiders in collaboration with several local residents who are also still reclaim a part of national park. Because their actions damage the environment and potential to pollute the upstream part of the watershed leading to the city of Palu. The authorities have asked the regional government and state police to curb and prohibit the mining. However, local residents oppose the actions of the authorities on the pretext they only do mining the people.

It can be said that the enforcement of the State law on any violation of the use of natural resources around the national park that occurs faces various obstacles. Both in terms of the substance or content of the regulation and the legal structure. It appears that there are a number of articles that are not synchronous between one regulation with another, causing different interpretations or understandings, moreover the resources of the apparatus are not supportive. Then the legal structure becomes difficult to work properly in accordance with the mandate of the law.

The national park authority as the person in charge of managing the national park is unable to enforce the regulation effectively. The main weakness of the enforcement of these state regulations is that they are not in accordance with the culture of public law or do not take a persuasive approach.

However, customary law that has been implemented from generation to generation by local communities around the national park is still respected and obeyed. So that a number of violations that occur in the legislation as a State law although some of them occur also within the environment of indigenous peoples but can be resolved through deliberation / customary justice.

Protection of natural resources according to customary law can be done by setting a number of prohibitions, restrictions, threats of sanctions, and procedures for restoring the situation. This is done by the totua there and figures who are believed to have a number of advantages that can solve some of the problems faced by the community.

There are five villages as location investigated for record the attitude of communities on the natural resources protection surround the national park. Petimbe represent of Kaili tribe, Sedoa and Watumaeta represent of Pekeurehua tribe, and Marena and Toro represent of Kulawi tribe.

Tabel 5. Villages customary rules on natural resources protection

\begin{tabular}{llllll}
\hline $\begin{array}{l}\text { Villages/ } \\
\text { Rules }\end{array}$ & Petimbe & Sedoa & Watumaeta & Marena & Toro \\
\hline Ombo & No & Yes & Yes & Yes & Yes \\
Palia & Yes & Yes & Yes & Yes & Yes \\
Koola & No & Yes & Yes & Yes & Yes \\
Taolo/dumpolo & Yes & Yes & Yes & Yes & Yes \\
\hline
\end{tabular}

Source: Field data

These villages showed that customary principles related to use natural resources around the national park still recognized. Except in Petimbe village people didn't know if there any ombo or kaolo. Its also difference with the other villages which more plural population, such migrant were settled since 1970's means their attitude to recognized local rules less than others.

Meanwhile, Sedoa, Watumaeta, Marena, and Toro inhabitants generally still have kinship or kinship with one another in one village even with the surrounding village. Kinship is very high influence on understanding and adherence to customary law itself. This can be seen from the respondent's answer and observations that show that the community members of the same customary association respond more quickly to the problem related to adat provisions that apply in their village. 
Toro and Marena villages are prominent because of their well implementation of all the customary law determine as a rule. Both of these villages consistently implement and uphold customary law, especially those related to the use of natural resources. So that every villager realizes the importance of protecting and protecting and complying with customary rules regarding the use and protection of natural resources.

In Totua's view there is Toro and Marena, the relationship between humans and the environment is an eternal relationship. The traditional concept of utilizing natural resources is called popahilo longa katuwua, in the concept of katuwua it is believed that on this earth (iwongko lino) there are three elements of life that have a reciprocal relationship namely humans, animals and plants.

Customary law was abided by the community since it is compatible to the practiced norms in the society. Due to this the villagers appreciate and respect the customary law provisions and the given penalty was a determinant factor for the obedience of villagers.

However, some infraction to the customary law pertinent to natural resources still taken place such as land ownership expropriation (kahua-hua oma oma do belo nia puena), drawing ahead other's land ownership (kahopu-hopu manako and kotoq. The customary law still take a role in solving these problems, so that the actors are processed through adat institutions. So that the balance of nature is maintained.

Basically the purpose of the existence of the customary is to manage the advantage forms including the conservation and preservation of natural/forest resources compatible with the local custom (Bendix, Eggert, \& Peselmann, 2012; Fremerey, 2002; Harris AO, 2016). The customary law as a combination of values and the need of human being who as a part of environment.

Nevertheless, state law established with natural/forest resources perseveration and conservation applying top down approach without consider local traditions faced many constraint. Because of legal culture that does not associate with any regulation will be resistant through many attitude of the people who affected of the law. Off course, they are prefer to obey what is it felt fairness than other (state law). There are many reason to refuse what they felt tend to threat or making them to be loss of opportunity in their live.

\section{Conclusion and Suggestion}

In general, customary law was respected since it was suitable with valuable norms adhered by local communities, due to this the villagers grace and appreciate the law provisions. In addition to this, the given sanction was a determined factor for the community to obey the customary law.

Some principles of customary law on natural resources protection such palia, ombo, kaola, taolo, and dumpola in pertinent to natural resource conservation. These principles are adhered to and has been hereditary for the communities around the national park. Its a guidance in developing mutual relation between men and nature.

The customary values on utilizing as well as protecting natural resources still complied by the tribes. They considered that adhering to customary law to protect natural resources around national parks is as important as protecting themselves from various problems. Therefore customary law is felt to better meet the needs of community law though, state law with formal approach when any infringement surround the national park. However, customary law principles still always need to be a sources for environmental law or related

\section{Acknowledgement}

I wish to deliver my thanks to Directorate of Higher Education of the Republic Indonesia for funding the research and my thank also come to Universitas Tadulako for the facilitation during the time of the research.

\section{References}

1. Acciaioli, G. (2008). environmentality reconsidered: indigenous to lindu conservation strategies and the reclaiming of the commons in central sulawesi, indonesia. NCCR North-South.

2. Banakar, R. (2015). normativity in legal sociology; methodological reflections on law and regulation in late modernity. Retrieved from www.springer.com

3. Bendix, R., Eggert, A., \& Peselmann, A. (Eds.). (2012). heritage regimes and the state. Göttingen: Universitätsverlag Göttingen. 
4. Blandy, S. (2016). socio-legal approaches to property law research. In S. Bright \& S. Blandy (Eds.), Researching Property Law (pp. 24-42). https://doi.org/10.1007/978-1-137-48618-9_3

5. Booth, A., \& Halseth, G. (2011). why the public thinks natural resources public participation processes fail: a case study of british columbia communities. Land Use Policy, 28(4), 898-906. https://doi.org/10.1016/j. landusepol. 2011.03.005

6. BPS Kabupaten Poso. (2018a). kabupaten poso dalam angka 2018. Poso: Badan Pusat Statistik Kabupaten Poso.

7. BPS Kabupaten Poso. (2018b). kecamatan lore utara dalam angka 2018. Poso: Badan Pusat Statistik Kabupaten Poso.

8. BPS Kabupaten Sigi. (2018a). kabupaten sigi dalam angka 2018. Sigi: Badan Pusat Statistik Kabupaten Sigi.

9. BPS Kabupaten Sigi (Ed.). (2018b). kecamatan kulawi dalam angka 2018. Sigi: Badan Pusat Statistik Kabupaten Sigi.

10. Burkard, G. (2002). Natural resource management in central sulawesi: past experience and future prospects. Research Project on Stability of Rain Forest Margins (STORMA), (8), 27.

11. Clifton, J., Acciaioli, G., Brunt, H., Dressler, W., Fabinyi, M., \& Singh, S. (2014). statelessness and conservation: exploring the implications of an international governance agenda. Tilburg Law Review, $19,9$.

12. Deschamps, V., \& Hartman, P. (2005). trends in forest ownership, forest resources tenure and institutional arrangements; are they contributing to better forest management and poverty reduction? The Nature Conservancy (TNC), 34. Bangkok: The Nature Conservancy (TNC).

13. Erasmi, S., Twele, A., Ardiansyah, M., Malik, A., \& Kappas, M. (2004). Mapping deforestation and land cover conversion at the rainforest margin in central sulawesi, indonesia. he tropical rain forests in indonesia are affected by socio-economic and ecological factors, 3, 10. Retrieved from http://www.eproceedings.org/

14. Fathoni, M. Y. (2013). konsep keadilan dalam pengelolaan dan pemanfaatan sumber daya alam menurut undang-undang pokok agraria tahun 1960. 16.

15. Fremerey, M. (2002). local communities as learning organizations: the case of the village of toro, central sulawesi, indonesia. [Working Paper Series]. Göttingen: Research Project on Stability of Rainforest Margins (STORMA),

16. Gantika, N., \& Wibowo, A. (2013). rata (rapid land tenure assessment) desa sedoa dan o'o, sulawesi tengah (Cetakan pertama). Jakarta: HuMa.

17. Harris AO, P. (2016). overcoming indigenous disadvantage: key indicators 2016. SCRGSP (Steering Committee for the Review of Government Service Provision), 3558.

18. Harwell, E. E., \& Lynch, O. J. (Eds.). (2002). whose resources?whose common good? towards a new paradigm of environmental justice and the national interest in indonesia. Center for International Environment Law (CIEL).

19. Herriman, N. (2017). management of biodiversity: creating conceptual space for indigenous conservation. Journal of Ecological Anthropology, 19(1). https://doi.org/10.5038/2162-4593.19.1.1184

20. Hertogh, M. (2018). Palgrave Socio-Legal Studies, Legal Consciousness and Legal Alienation in Everyday Life. Retrieved from http//www.palgrave.com/gp/series/14679

21. Hidayat, Y., Sinukaban, N., Pawitan, H., \& Tarigan, S. D. (2007). Dampak Perambahan Hutan Taman Nasional Lore Lindu Terhadap Fungsi Hidrologi Dan Beban Erosi (studi Kasus Daerah Aliran Sungai Nopu Hulu, Sulawesi Tengah). 9.

22. Keil, A., Zeller, M., Wida, A., Sanim, B., \& Birner, R. (2008). What determines farmers' resilience towards ENSO-related drought? An empirical assessment in Central Sulawesi, Indonesia. Climatic Change, 86(3-4), 291-307. https://doi.org/10.1007/s10584-007-9326-4

23. Li, T. M. (2001). Agrarian Differentiation and the Limits of Natural Resource Management in Upland Southeast Asia. IDS Bulletin, 32(4), 88-94. https://doi.org/10.1111/j.1759-5436.2001.mp32004011.x

24. Mehring, M., \& Stoll-Kleemann, S. (2011). How Effective is the Buffer Zone? Linking Institutional Processes with Satellite Images from a Case Study in the Lore Lindu Forest Biosphere Reserve, Indonesia. Ecology and Society, 16(4). https://doi.org/10.5751/ES-04349-160403

25. Moeljoprawiro, S., \& Faqih, A. M. (1998). Access To the Genetic Resources and Utility's Regulation. Jakarta.

26. Murray Li, T. (2000). Articulating Indigenous Identity in Indonesia: Resource Politics and the Tribal Slot. Comparative Studies in Society and History, 42(1), 149-179. https://doi.org/10.1017/S0010417500002632

27. Perda Sulteng DPTNLL. Peraturan Daerah Provinsi Sulawesi Tengah Nomor 6 Tahun 2006 Tentang Daerah Penyanggah Taman Nasional Lore Lindu. , Pub. L. No. 6/2006, Perda (2006). 
28. Schrijver, N. (1997). Sovereignty Over Natural Resources, Balancing Rights and Duties. New York: Cambridge University Press.

29. UURI 4/2009. UU RI No. 4 Tahun 2009 Tentang Pertambangan Mineral dan Batubara. , Pub. L. No. 4, 4 (2009).

30. UURI 5/1990 KSDAE. UU RI No.5 Tahun 1990 Tentang Konservasi Sumber Daya Alam dan Ekosistem. , Pub. L. No. 49, 512 (1990).

31. UURI 18/2013. UU RI No. 18 Tahun 2013 Tentang Pemberantasan Perusakan Hutan., Pub. L. No. 18/2013, 92 (2013).

32. UURI 32/2009 PPLH. UU RI No. 32 Tahun 2009 Tentang Perlindungan dan Pengelolaan Lingkungan Hidup. , Pub. L. No. 140, 110 (2009).

33. UURI 41/1999 UUK. UU RI No. 41 Tahun 1999 Tentang Kehutanan., Pub. L. No. 167, 42 (1999). 